\title{
Evaluation of Soil Fertility of Large Cardamom (Amomum subulatum) Field under Different Organic Manure Management
}

\author{
Richa Neupane* and Baburam Khanal \\ Agriculture and Forestry University, Faculty of Agriculture, Rampur, Chitwon, Nepal \\ *Corresponding Author: Richa Neupane, Agriculture and Forestry University, Faculty of Agriculture, Rampur, Chitwon, Nepal.
}

Received: June 07, 2019; Published: August 26, 2019

DOI: 10.31080/ASAG.2019.03.0629

\begin{abstract}
The research was conducted to assess the impact of different sources of organic manures on soil properties under large cardamom cultivation in Hangdewa and Phurumbu block, Taplejung, Nepal. The different sources of organic manures along with one control without application of manures and fertilizers was classified into five treatments, i.e. control, farm yard manure (FYM), FYM+ cattle urine, cattle urine only and vermi-compost. Focused group discussion was conducted to identify the preference for different sources of manures used by farmers for large cardamom cultivation. Composite soil samples were taken from each treatment to analyse soil texture, soil organic matter (SOM), soil pH, soil nitrogen, soil phosphorus, soil potassium and micronutrients such as boron and Zinc. Laboratory analysis of the collected soil sample revealed that the soil texture among all treatments were sandy loam type. The highest soil organic matter (5.84\%) was found in vermi-compost which was on par with FYM+cattle urine and FYM. Soil pH was recorded highest (5.35) in cattle urine followed by vermi-compost and FYM+cattle urine. Soil nitrogen was found highest (0.25\%) in vermicompost similar with cattle urine, FYM + cattle urine and FYM. Soil phosphorus was observed higher (19.69 mg/kg) in vermi-compost followed by cattle urine. Soil potassium was observed significantly higher $(65.47 \mathrm{mg} / \mathrm{kg})$ in vermi-compost. Boron content was found to be highest $(0.60 \mathrm{mg} / \mathrm{kg})$ in vermi-compost followed by FYM + cattle urine. Zinc content was recorded highest (2.61 mg/kg) in FYM + cattle urine which was on par with vermi-compost $(2.5 \mathrm{mg} / \mathrm{kg})$. Hence, nutrient status of soil applied improved significantly with different sources of organic manures compared to the control.
\end{abstract}

Keywords: Soil Fertility; Cardamom; Organic Manure

\section{Introduction}

Soil fertility is essential for increasing productivity and sustainability of Nepalese Agriculture. Soil physical, chemical and biological properties are highly influenced under the application of soil organic matter (SOM) by increasing the essential nutrients in soil. SOM also enhance soil quality and offer option for environmentally friendly crop production [1,2]. Addition of organic matter through animal manures, compost and crop residue have been established because it helps to increase crop yield and maintain soil fertility. Use of organic amendments such as animal manures, hay resi- dues and mulch enhanced soil fertility and significantly increased crop yield (Bwamiki, 1998 and Johnston., et al. 1995). Soil organic amendments are the vital parts of nutrient management program for sustainable agriculture as these have beneficial effect on soil and crop yield. Organic and inorganic nutrients application play an essential part of soil management that helps in maintaining of soil quality contributing to increasing productivity of the crop [3]. Use of organics not only supplies nutrients safely but also provides soil resilience and also feed the organisms that build the soil structure which ultimately strengthen the soil fertility. 
Concentrations of carbon, phosphorus, potassium, calcium and magnesium were found in greater amounts in soils applied with organic matter and farm wastes [4]. Nutrients such as nitrogen, phosphorus, potassium availability in soil can be increased because of enhanced cation exchange capacity of soil (Chan., et al. 1992) with the organic amendments.

Large cardamom farmers in Taplejung, Nepal have started facing a reduction in yield due to changing climatic conditions, soil conditions and pests and diseases [5]. The major reasons for the declining productivity in large cardamom include lack of technical knowledge among the farmers about its cultivation as well as timely unavailability of inputs and low use of compost and organic manures, and these are considered as major perpetrators for the declining productivity [5]. Soil replenishment and soil fertility improvement through application of manures or mulching are not primarily practiced in the old farms [6]. Different soil amendments practices which are readily available through farm wastes such as FYM, urine, vermi-compost have not been used in large cardamom field frequently due to lack of awareness among the farmers as well as their ignorance towards such practices. In addition, the soils in the farmer's field have not been tested for nutrient analysis as a result farmers are unaware of the essential nutrients lacking in the field which affects the soil fertility.

Realizing these facts, importance of soil management practices by the use of FYM, urine, vermi-compost that are chief organic sources are relevant for large cardamom farming for improvement of the soil fertility contributing to enhanced productivity. Nepal being country with agricultural background, majority of the farmers in the high hills use FYM as the major source of plant nutrients based on traditional knowledge and techniques followed for generations. In the past, this contributed to the maintenance of a balanced input-output ratio of SOM. The majority of farmers (> 85\%) apply FYM and/or compost in their fields (Maskey., et al. 2002). However, a decline in the soil organic carbon stocks due to changes in land use, intensive cultivation and poor management of manure has been observed (Gami., et al. 2001 and Upadhyaya., et al. 2005). In the present study evaluates FYM, cattle urine and vermicompost as alternative organic nutrient sources. In addition, these organic sources are also used in combination and stand alone as different treatments.

\section{Materials and Methods}

Research site

The research was conducted in Hangdewa and Phurumbu, the block area for cardamom of Taplejung district, Nepal under Prime Minister Agriculture Modernization Project. With an area above $100 \mathrm{Ha}$ under large cardamom cultivation, Hangdeva and Phurumbu, located at $27^{\circ} 21^{\prime} 0 \mathrm{~N} 87^{\circ} 40^{\prime} 0 \mathrm{E}$ with an altitude of 1441 meters (4730 feet), were selected as cardamom block.

\section{Experimental design}

The research was carried out in Randomized Complete Block design (RCBD).

Various sources of organic manures management practices on large cardamom field already adopted by farmers were considered as treatments. Five organic manure management practices viz. control, FYM, FYM + cattle urine, cattle urine and vermi-compost were selected as treatments for study and each treatment were replicated five times to maintain homogeneity in research.

The various organic manure management practices followed by farmers were identified through focused group discussions and key informant interview with major large cardamom growers of the block area (Hangdeva and Phurumbu). For each practice, 500 $\mathrm{m}^{2}$ area having 222 large cardamom plants were selected for study which was considered as one sampling plot.

\section{Treatments description}

The treatments were:

- $\quad$ Treatment 1: Control

- $\quad$ Treatment 2: FYM (@4kg per plant)

- $\quad$ Treatment 3: FYM + Cattle Urine (FYM @4kg per plant and Cattle Urine @1liter mixed with 5liters of water)

- $\quad$ Treatment 4: Cattle Urine only (@2liter per plant in split doses 1liter mixed with 5liter of water)

- $\quad$ Treatment 5: Vermi-Compost (@2kg per plant)

\section{Soil sample collection and preparation}

Soil samples were collected from each category following simple random sampling technique. Altogether 25 samples were collected randomly for analysis for soil physical and chemical properties. Five subsamples were taken from each plot for $30 \mathrm{~cm}$ depth and composite sample was prepared for each plot. Bucket auger was 
used for soil samples collection. The collected soil samples were labelled with tagging for ease identification in lab and were brought to regional soil testing laboratory, Hetauda, Makwanpur, Nepal. Soil samples were analysed for the texture, soil $\mathrm{pH}$, soil organic matter, nitrogen, phosphorus and potassium and micronutrient boron and zinc content of the soil. Data analysis were carried out using MS Excel and Gen-Stat software. Analysis of Variance (ANOVA) were performed using Gen-Stat to differentiate the differences between the means of treatments. Duncan's Multiple Range Test (DMRT) at $5 \%$ probability levels was used for mean separation.

\section{Results and Discussions}

\section{Soil texture}

The soil texture observed during the soil physical property analysis was found to be sandy loam type (Table 1). There was not any difference between the soil textural properties. Therefore, no changes were found to occur as a result of textural characteristics.

\begin{tabular}{|l|c|c|c|c|}
\hline Treatments & $\begin{array}{c}\text { Clay } \\
\text { (\%) }\end{array}$ & $\begin{array}{c}\text { Sand } \\
\text { (\%) }\end{array}$ & $\begin{array}{c}\text { Silt } \\
\text { (\%) }\end{array}$ & $\begin{array}{c}\text { Texture } \\
\text { class }\end{array}$ \\
\hline Control & 9 & 60 & 32 & SL \\
\hline $\begin{array}{l}\text { Farm Yard Manure } \\
\text { (FYM) }\end{array}$ & 5 & 62 & 34 & SL \\
\hline FYM+ Cattle Urine & 4 & 70 & 26 & SL \\
\hline Cattle Urine & 5 & 70 & 26 & SL \\
\hline Vermi-Compost & 5 & 66 & 30 & SL \\
\hline
\end{tabular}

Table 1: Soil texture with the proportions of sand, silt and clay.

Note: SL represents Sandy Loam type

Soil chemical properties

\begin{tabular}{|c|c|c|c|c|c|c|c|}
\hline Treatments & $\begin{array}{c}\text { Organic } \\
\text { Matter (\%) }\end{array}$ & pH & $\begin{array}{c}\text { Nitrogen } \\
(\%)\end{array}$ & $\begin{array}{c}\text { Phosphorus } \\
\text { (mg/kg) }\end{array}$ & $\begin{array}{c}\text { Potassium } \\
\text { (mg/kg) }\end{array}$ & $\begin{array}{c}\text { Boron } \\
\text { (mg/kg) }\end{array}$ & $\begin{array}{c}\text { Zinc } \\
\text { (mg/kg) }\end{array}$ \\
\hline Control & $4.11^{\mathrm{a}}$ & $4.68^{\mathrm{a}}$ & $0.15^{a}$ & $7.30^{\mathrm{a}}$ & $39.38^{a}$ & $0.04^{\mathrm{a}}$ & $1.45^{\mathrm{a}}$ \\
\hline FYM & $5.38^{\mathrm{bc}}$ & $4.77^{\mathrm{ab}}$ & $0.22^{\mathrm{b}}$ & $12.99^{b}$ & $61.37^{b}$ & $0.25^{b}$ & $1.89^{\mathrm{b}}$ \\
\hline FYM+Cattle Urine & $5.62^{\mathrm{bc}}$ & $4.44^{\mathrm{a}}$ & $0.24^{\mathrm{b}}$ & $16.98^{c}$ & $58.58^{\mathrm{b}}$ & $0.49^{d}$ & $2.61^{c}$ \\
\hline Cattle Urine & $5.20^{\mathrm{b}}$ & $5.34^{\mathrm{b}}$ & $0.23^{\mathrm{b}}$ & $18.55^{\mathrm{cd}}$ & $61.03^{\mathrm{b}}$ & $0.37^{\mathrm{c}}$ & $2.33^{c}$ \\
\hline Vermi-compost & $5.83^{c}$ & $4.78^{\mathrm{ab}}$ & $0.24^{\mathrm{b}}$ & $19.69^{d}$ & $65.47^{\mathrm{b}}$ & $0.60^{\mathrm{e}}$ & $2.49^{c}$ \\
\hline LSD (0.05) & $0.45^{* *}$ & $0.57^{*}$ & $0.02^{* *}$ & $1.96^{* *}$ & $6.52^{* *}$ & $0.06^{* *}$ & $0.41^{* *}$ \\
\hline SeM & 0.21 & 0.27 & 0.01 & 0.92 & 3.07 & 0.03 & 0.19 \\
\hline $\mathrm{CV}(\%)$ & 6.5 & 8.9 & 7.7 & 9.7 & 8.5 & 14.7 & 14.3 \\
\hline Grand Mean & 5.23 & 4.80 & 0.22 & 15.1 & 57.16 & 0.35 & 2.15 \\
\hline
\end{tabular}

Table 2: Effect of different treatments on soil chemical properties.

Note: Means followed by same letter in the column are not significant at $5 \%$ level of significance as determined by DMRT. $* *$ represents significant at $0.001 \mathrm{P}$ level.

\section{Soil organic matter}

The highest SOM (5.83 \%) was observed under soil applied with vermi-compost which was not significantly different from soil applied with FYM + cattle urine and soil applied with FYM. The lowest soil organic matter (4.11\%) was found in no organic manure applied large cardamom field i.e. control (Table 2). The higher level of organic matter may be due to the presence of already present organic matter content in Vermi-compost as a result of decomposi- tion of cardamom leaves and leaves and parts of Alnus nepalensis on soil. Organic matter was found to higher in Vermi-compost as compared to soil receiving other sources of organic manures [7].

Soil pH

Soil applied with cattle urine recorded the highest $\mathrm{pH}$ level (5.34) while the least $\mathrm{pH}$ level (4.44) was found in soil applied with FYM + cattle urine. However, it was observed that the pH level of 
the control as well as other treatments was found to be acidic (Table 2). Organic acid production during organic matter decomposition might be the reason for low $\mathrm{pH}$ in soil. This is also consistent with Groenigen., et al. [8] and Powell., et al. [9] that the application of Urine increased soil pH. However, Srinivasamurthy., et al. [10] reported that application of FYM and human urine increased soil $\mathrm{pH}$ as compared to cattle urine and control.

\section{Soil nitrogen}

The least nitrogen level was found on control $(0.15 \%)$ while the highest was observed on vermi-compost $(0.28 \%)$. However, it was found that except control $(0.15 \%)$ all other treatments showed higher level of nitrogen as compared with other treatments (Table 2 ). This is due to the addition of organic manures, nitrogen level increased as compared to control treatment. The amount of soil total nitrogen increased with the application of urine and FYM according to Sharma., et al. [11,12]. The amount of nitrogen content in the soil was found to be higher in soil applied with vermi-compost than the soil applied with FYM [13]. Amount of nitrogen increased significantly after incorporating vermi-compost into the soil [14-16].

\section{Soil phosphorus}

The highest phosphorus (19.69 mg/kg) was found on vermicompost applied soil followed by cattle urine, FYM + cattle urine and FYM. The least $(7.30 \mathrm{mg} / \mathrm{kg})$ was recorded in control treatment (Table 2). Similarly, it was observed that the phosphorus content in Control was relatively low. Vermi-compost application significantly increased soil phosphorus level higher than the soil applied with FYM (Gaurav et al., 2016).

\section{Soil potassium}

Soil applied with vermi-compost was found to show the highest potassium level ( $65.47 \mathrm{mg} / \mathrm{kg}$ ) followed by FYM which was not significantly different from cattle urine (Table 2). The least potassium level was observed in control (39.38 mg/kg). Vermi-compost application reported to increase soil potassium higher than the FYM application in soil [13]. Vermi-compost application increased the potassium content as compared with the soil [17]. Application of vermi-compost recorded significantly higher available $\mathrm{K}$ than FYM [18].

Soil nitrogen, phosphorus and potassium

Bhaskaran., et al. [19] commented on the increase of potassium and nitrogen in soil with application of vermi-compost than that with FYM application (Table 2). Kumar., et al. [20] reported that nitrogen and phosphorus level was found higher in organic manures as compared with the control. Nitrogen, phosphorus and potassium in soil increased by vermi-compost application as mentioned in [21]. Higher level of nitrogen, phosphorus and potassium was obtained with soil applied with vermi-compost as compared to FYM and other liquid manures [22]. Venkatesh [23] supported the result illustrating that the incorporation of vermi-composts into the soil increased the amount of soil potassium and soil phosphorus.

\section{Soil boron}

The results as obtained from the study showed that the highest soil boron $(0.60 \mathrm{mg} / \mathrm{kg})$ was resulted in soil treated with vermi-compost which is followed by FYM + cattle urine, cattle urine and FYM (Table 2). The least amount of boron was recorded in the control treatment $(0.04 \mathrm{mg} / \mathrm{kg})$. Reddy and Reddy [24], found that vermi-compost application had higher in boron content than soils that received other source of organic manure.

\section{Soil zinc content}

Zinc was found to be highest on FYM + cattle urine $(2.61 \mathrm{mg} /$ $\mathrm{kg}$ ) followed by cattle urine and FYM. Vermi-compost $(2.49 \mathrm{mg} /$ $\mathrm{kg}$ ) was found to have no significant difference with FYM+ cattle urine (Table 2). Zinc was found to increase with the soil treated with vermi-compost than with the soil treated with FYM only and with the control treatment [17]. According to Bhaskaran [19] soil zinc content was increased with vermi-compost application. Zinc content was found to be higher in vermi-compost application than that in control treatment [25-53].

\section{Conclusion}

The results of the study showed that the soil nitrogen, phosphorus, potassium and micronutrients boron and zinc were found to be higher in vermi-compost which might be due to higher nutrient content in vermi-compost. Similarly, the organic matter and soil pH were found to be higher in cattle urine. Soil pH might be higher in cattle urine due to the organic acid production during organic matter decomposition. Control soil showed the lowest amount of SOM, soil nitrogen, phosphorus and potassium and micronutrients boron and zinc due to the unavailability of nutrients from organic and inorganic sources. Similarly, soil textural class of all treatments were sandy loam type. However, it was found that the soils in the cardamom field are rich in SOM despite the application of any or- 
ganic sources because cardamom requires more than $1 \%$ of soil organic matter for its growth. Similarly, boron was found in trace amount in all other treatments except vermi-compost. Thus, soil chemical properties were highly enhanced under vermi-compost, cattle urine and FYM + cattle urine application.

\section{Bibliography}

1. Bauer A and Black A. "Quantification of the effect of soil organic matter content on soil productivity". Soil Science society of American Journal 58.1 (1994): 185-193.

2. Parkin Doran J W and Timothy B. "Defining and Accessing Soil Quality". Defining Soil Quality for Sustainable Environment (1994): 1-21.

3. Korikanthimath V S. "Studies on chemical composition of coffee pulp and organic recycling in the coffee and cardamom cropping system". Crop Research Hisar 20.2 (2000): 350-354.

4. Clark M., et al. "Changes in soil chemical properties resulting from organic and low-input farming practices". Agronomy Journal 90 (1998): 662-671.

5. Chaudhary R and Vista S. "Proceedings of the Stakeholders Consultation Workshop on Large Cardamom development In Nepal". Khumaltar , Nepal: Commercial Crop Division , NARC (2015).

6. Himalika. "Package of Practice of Large Cardamom". Taplejung: ICIMOD (2015).

7. Rao K., et al. "Effect of Tendu Leaf Litter Vermicompost on Physico-Chemical Properties of Soil". International Journal of Pharmaceutical Research and Bioscience 4.4 (2015): 24-35.

8. Groenigen V W J. "Nitrous oxide emission from urinetreated soil as influenced by urine composition and soil physical conditions". In Soil Biology and Biochemistry 37.3 (2005): 463-473.

9. Powell JM., et al. "Urine effects on soil chemical properties and the impact of urine and dung on pearl millet yield". Experimental Agriculture 34.3 (1998): 259-276.

10. Srinivasamurthy D., et al. "Human Urine an Alternative to Chemical Fertilizers in Crop Production" (2012).

11. Sharma R., et al. "Effects of Cattle Urine and FYM on Yield of Broccoli and Soil properties". Journal of AgriSearch 3.3 (2016): 157-160.
12. Sharma Shah., et al. "Effect of cattle urine and FYM on yield of broccoli and soil properties" (2016).

13. Singh G. "Comparative study of Manures produced from wastes". International Journal of Advance Research, Ideas and Innovations in Technology 2.6 (2016).

14. Sreenivas C., et al. "Vermicomposts: a viable component of IPNSS in nitrogen nutrition of ridgegourd". Annuals of Agricultural Research (2000).

15. Kale R B. "Influence of vermicompost application on the available macronutrients and selected microbial populations in a paddy field". Soil Biology and Biochemistry 24.12 (1992): 1317-1320.

16. Nenthra $\mathrm{N} \mathrm{J}$. “China aster cultivation using vermicomposts as organic amendment" (1999).

17. Ravimycin T. "Effects of Vermicompost (VC) and Farmyard Manure (FYM) onthe germination percentage growth biochemical and nutrientcontent of Coriander (Coriandrum sativum L.)". International Journal of Advanced Research in Biological Sciences 3.6 (2016): 91-98.

18. Jayaprakash., et al. "Effect of Organics and Inorganics on Soil Properties and Available Nutrient Status of Soil After Harvest of Maize Crop Under Irrigation". Karnataka Journal of Agricultural Science 17.2 (2004): 311-314.

19. Bhaskaran., et al. "Effect of organic farming on soil fertility, yield and quality of crops in the tropics". (2009).

20. Kumar M D., et al. "Effect of integrated nutrient management on yield and nutrient content by cardamom(Elettaria cardamomum L. Maton.)". Karnata Journal of Agricultural Science (2009).

21. Gopinath K., et al. "Utilization of Vermi-compost as a Soil Ammendment in Organic Crop Production". Dynamic Soil, Dynamic Plant 4.1(2010): 48-57.

22. Balaji. "Study on Vermicomposting and its influence on plant growth" (1994).

23. Venkatesh PP. "Effect of in situ vermiculture and vermicomposts on availability and plant concentration of major nutrients in grapes". Karnataka Journal of Agricultural Sciences 11.1 (1998). 
24. Reddy B and Reddy M. "Effect of integrated nutrient management on soil available micro nutrients in maize soyabean cropping system". (1999).

25. Balbhim CL., et al. "Effect of organic and chemical fertilizers on cluster beans (Cyamopsis tetragonolobus)". European Journal of Experimental Biology 5.1 (2015): 34-38.

26. Allan Fulton FA. "Primary Plant Nutrients: Nitrogen, Phosphorus and Potassium". (2010).

27. Adeoluwa 0 and Suleiman O. "Effect of human urine on the growth of performances of Jathropha curcas seedlings and some soil health indices" (2012).

28. Albanell EP. "Chemical changes during vermicomposting of sheep manure mixed with cotton industrial wastes" Biology and Fertility of Soils 6.3 (1998): 266-269.

29. Aracon N. "Applications of Vermicomposts to tomatoes and peppers grown in the field and strwaberries grown under high plastic tunnels" (2002).

30. Chaudhary S., et al. "Cow Urine :A Boon for Sustainable Agriculture". International Journal of Current Microbiology and Applied Sciences 6.2 (2017): 1824-1829.

31. DADO. In DADO Profile. Taplejung: District Agriculture Development Office, Taplejung (2072/73).

32. DAD0. "Annual Agriculture Development Program and Satistical Yearbook. Dhadingbeshi: District Agriculture Development Office, Dhading" (2072/73).

33. Dhital S. "Alainchi Kheti. Khumaltar, Lalitpur: National Spice crop Development Programme". (2069).

34. Edmeades D. "Nutrient Cycling in Agroecosystems" (2003).

35. Efthimiadou A., et al. "Combined Organic/Inorganic Fertilization Enhances Soil Quality and Increased Yield, Photosynthesis and Sustainability of Sweet Maize Crop" Australian Journal of Crop Science 4.9 (2010).

36. Escobar M A. "Temporal Changes of Selected Chemical Properties in Three Manure Amended soils of Hawaii" Bioresource Technology 99.18 (2008): 8649-8654.

37. Khader K A. "Fertilizing Cardamom-its importance." In Cardamom (1997).
38. Khalil M., et al. "Nitrogen Transformation and Emission of Greenhouse Gases from Three Acid Soils of Humid Tropics Amended with N Sources and Moisture Regime". Communications in Soil Science and Plant Analysis 32.17 (2001): 29092924.

39. Khan N., et al. "Effect of tillage and Farm Yard Manure on Physical properties of soil" (2010).

40. M.Lemlem M A. "Integrated Agronomic Crop Managements to Improve the Productivity under Terminal Drought" (2012).

41. Marino C. "Urine composition depends on certain factors" (2008).

42. Myint AY. "Nitrogen Dynamics in a Paddy Field fertilized with mineral and organic nitrogen sources". American-Eurasian Journal of Agricultural and Environmental Sciences (2010).

43. Ndayegamiye AA. "Effect of long term pig slurry and solid cattle manure application on soil chemical and Biological properties" Canadian Journal of Soil Science 69.1 (1989): 39-47.

44. Nwite J. "Effect of different urine sources on soil chemical properties and maize yield in Abakaliki, Southeastern Nigeria" IJAAR 3 (2015): 31-36.

45. Palm CA. "Organic inputs for soil fertility management in tropical agroecosystems:Application of organic database". Agriculture, Ecosystems and Environment 83.1-2 (2001): 27-42.

46. Pathak HA. Supplying Capacity of an Ustochrept Amended with Manures, Urea and Their combinations (1994).

47. Poudel DP. Improved Cardamom Cultivation Technology. Pakhribas, Dhankuta: NARC Publication. (2073).

48. Prasad B and Sinha S. "Long-Term Effects of Fertil- izers and Organic Manures on Crop Yields, Nutrient Balance, and Soil Properties in Rice-Wheat Cropping System in Bihar". (2017).

49. Rahman MI. "Influence of Organic Matter on Nitrogen Mineralization Pattern in Soils under Different Moisture Regimes". International Journal of Agriculture and Biology 15.1 (2013): 55-61.

50. Saunders W. "Effect of Cow Urine and its major constituents on Pasture properties" New Zealand Journal of Agricultural Research 25.1 (1982): 61-68. 
51. Veeresha S G. "Effect of organic production practices on yield and soil health of irrigated maize as influenced by various levels of FYM and cattle urine application" CAB Direct 32.4 (2014): 627-630.

52. Wong MA. "Role of Organic Matter in Alleviating Soil Acidity" (2003).

53. Zhanjun Liu Q R. "Effects of inorganic and organic amendment on soil chemical properties, enzyme activities, microbial community and soil quality in yellow clayey soil" PLOS ONE 12.3 (2017): e0172767.

Volume 3 Issue 9 September 2019

(C) All rights are reserved by Richa Neupane and

Baburam Khanal.

Citation: Richa Neupane and Baburam Khanal. "Evaluation of Soil Fertility of Large Cardamom (Amomum subulatum) Field under Different Organic Manure Management". Acta Scientific Agriculture 3.9 (2019): 169-175. 